\title{
Chronic Blockade of AT2-subtype Receptors Prevents the Effect of Angiotensin II on the Rat Vascular Structure
}

\author{
Bernard I. Levy, Joelle Benessiano, Daniel Henrion, Lidia Caputo, Christophe Heymes, ${ }^{*}$ Micheline Duriez, Pierre Poitevin, \\ and Jane Lise Samuel* \\ Institut National de la Santé et de la Recherche Médicale, Unit 141, Cardiovascular Dynamics and Vascular Biology and *Unit 127, IFR \\ Circulation Lariboisière, Université Denis Diderot, Paris, France 75010
}

\begin{abstract}
Angiotensin II (Ang II) is both a vasoactive and a potent growth-promoting factor for vascular smooth muscle cells. Little is known about the in vivo contribution of AT1 and AT2 receptor activation to the biological action of Ang II. Therefore, we investigated the effect of AT1 or AT2 subtype receptor chronic blockade by losartan or PD123319 on the vascular hypertrophy in rats with Ang II-induced hypertension.

Normotensive rats received for 3 wk subcutaneous infusions of Ang II (120 ng/kg per min), or Ang II + PD 123319 (30 $\mathrm{mg} / \mathrm{kg}$ per d), or Ang II + losartan (10 $\mathrm{mg} / \mathrm{kg}$ per d) or PD 123319 alone, and were compared with control animals.

In normotensive animals, chronic blockade of AT2 receptors did not affect the plasma level of angiotensin II and the vascular reactivity to angiotensin II mediated by the AT1 receptor. Chronic blockade of AT1 in rats receiving Ang II resulted in normal arterial pressure, but it induced significant aortic hypertrophy and fibrosis. Chronic blockade of AT2 receptors in Ang II-induced hypertensive rats had no effect on arterial pressure, but antagonized the effect of Ang II on arterial hypertrophy and fibrosis, suggesting that in vivo vasotrophic effects of Ang II are at least partially mediated via AT2 subtype receptors. (J. Clin. Invest. 1996. 98: 418-425.) Key words: angiotensin II • angiotensin receptors - vascular hypertrophy • hypertension
\end{abstract}

\section{Introduction}

Angiotensin II (Ang II), ${ }^{1}$ the main effector peptide of the renin-angiotensin system has long been known to play a major role in the regulation of blood pressure and body fluid homeostasis. Moreover, Ang II has been reported to induce hyperplasia and/or hypertrophy in cultured aortic smooth muscle cells (1-4) in small resistance arteries (5) and in cardiomyocytes (6). The tissue response to Ang II is mediated by specific receptors located on the cell surface. As defined by their pharmacological receptors, there are two main subtypes of Ang II receptors: AT1 and AT2, which are specifically blocked by

Address correspondence to Bernard Levy, INSERM Unit 141, Hôpital Lariboisière, 75010 Paris, France. Phone: 331-42-85-86-72; FAX: 331-42-81-31-28.

Received for publication 18 September 1995 and accepted in revised form 1 May 1996.

1. Abbreviation used in this paper: Ang II, Angiotensin II.

J. Clin. Invest.

(C) The American Society for Clinical Investigation, Inc.

0021-9738/96/07/0418/08 \$2.00

Volume 98, Number 2, July 1996, 418-425 losartan and PD123319, respectively (7). The AT1 receptor subtype, predominant in the vascular system, mediates most of the actions of Ang II closely associated with the regulation of vascular tone and extracellular fluid volume (8-12). Much less is known regarding the contribution of AT2 receptor activation to the biological actions of Ang II. The relative abundance of AT2 subtype receptors in many fetal tissues supports a role of AT2 during development $(13,14)$. Furthermore, a key role for the AT2 subtype receptor is suggested by several studies that correlate enhanced AT2 receptor expression with cardiovascular system disease states such as diabetes (15), postmyocardial infarction (16), ischemia (17), and hypertension (18); e.g., when cardiovascular remodeling is involved. The ability of a tissue to change the expression of AT1 receptors to AT2 has been described in experimentally induced vascular injury (19, 20), suggesting that Ang II may also play a role, through AT2 receptors, in smooth muscle cell differentiation and proliferation. Furthermore, by transfecting an AT2 receptor expression vector into the balloon-injured rat carotid artery, Nakajima et al. (21) reported that overexpression of the AT2 receptor attenuated neointimal formation.

Despite a considerable number of molecular and cellular studies, there is no available data concerning the in vivo role of the AT2 receptor on the cardiovascular remodeling associated with the renin-angiotensin system. Therefore, the aim of this study was to investigate the effect of AT2 subtype receptor blockade on the vascular hypertrophy of rats receiving chronic administration of Ang II. Furthermore, we tried to dissociate angiotensin II-induced hypertension from vascular hypertrophy by treating rats with simultaneous infusions of angiotensin II plus the AT1 blocker losartan.

\section{Methods}

\section{Experimental model}

The study was performed in 80 male 12-wk-old normotensive Wistar rats weighing $300 \pm 20$ g. Osmotic mini-pumps (2ML4; Alza Corp., Palo Alto, CA) were implanted subcutaneously in the back of the neck during sodium pentobarbital (50 mg/kg i.p.) anesthesia. Pumps were filled with sterile saline vehicle, or with Ang II (Asp-Arg-ValTyr-Ile-His-Pro-Phe, and acetate salt; Sigma Chemical Co., St. Louis, MO) saline solution $(1 \mathrm{mg} / \mathrm{ml})$ or with PD123319 (provided by IdRS, Suresnes, France) saline solution $(660 \mathrm{mg} / \mathrm{ml})$. Infused solutions were administered for $22 \mathrm{~d}$ at a constant rate of $2.5 \mu \mathrm{l} / \mathrm{h}$ corresponding to an Ang II infusion of $120 \mathrm{ng} / \mathrm{kg}^{-1}$ per min, and to a PD123319 infusion of $21 \mu \mathrm{g} / \mathrm{kg}^{-1}$ per min $\left(30 \mathrm{mg} / \mathrm{kg}^{-1}\right.$ per d). Losartan (provided by DuPont-Merck Pharmaceutical Co., Wilmington, DE) was given in drinking water $(10 \mathrm{mg} / \mathrm{kg}$ per $\mathrm{d})$.

The rats were randomly assigned to one of the following five groups: control $(n=20)$, receiving subcutaneous infusion of vehicle solution; Ang II $(n=12)$, receiving subcutaneous infusion of Ang II in the same vehicle; Ang II + PD123319 $(n=12)$, receiving simultaneous subcutaneous infusion of Ang II solution and PD123319; PD123319 $(n=12)$, receiving subcutaneous infusion of PD123319 
alone $(30 \mathrm{mg} / \mathrm{kg}$ per d); and Ang II + losartan $(n=12)$, receiving simultaneous subcutaneous infusion of Ang II solution and losartan $(10 \mathrm{mg} / \mathrm{kg}$ per $\mathrm{d})$ in the drinking water.

In an additional set of experiments, we tested the effect of chronic treatment with PD123319 on the vascular reactivity to phenylephrine and to angiotensin II. Rats receiving chronic administration of PD123319 $(n=6)$ were compared to six control rats receiving subcutaneous infusion of vehicle solution for $3 \mathrm{wk}$.

For each rat, systolic blood pressure was measured every week by the tail-cuff method (BP recorder 8006; W+W Electronic, Apelex, France). The conscious rats were warmed with the cuff and the pulse wave transducer set around the tail for $\sim 10 \mathrm{~min}$ before each systolic blood pressure measurement.

At the end of the treatment period, all rats were anesthetized with sodium pentobarbital (50 mg/kg i.p.) and used for hemodynamic studies; they were then killed and tissue samples were removed to perform morphological study.

The surgical procedure and hemodynamic measurements have been described in detail elsewhere $(22,23)$. Briefly, anesthetized rats were placed on a thermoregulated heating pad, intubated, and ventilated with a rodent respirator (680; Harvard Apparatus, Inc., South Natick, MA). A microtip pressure transducer (2-F; Millar Instruments, Inc., Houston, TX) was inserted into the right carotid artery to simultaneously record the carotid pressure and diameter.

Measurement of carotid arterial diameter. A high resolution pulse echo tracking device (NIUS, SMH; Capital Medical Service, Switzerland) (24) was used to acquire backscattered radio frequency data from the carotid artery. The probe consisted of a $10 \mathrm{-MHz}$ strongly focused piezoelectric transducer (5.2 $\mathrm{mm}$ diameter, $11 \mathrm{~mm}$ focal length) operating in the pulse-echo mode. The $-10-\mathrm{dB}$ beam width is $0.3 \mathrm{~mm}$ at the focal point, and the depth of field at $-10 \mathrm{~dB}$ is $5 \mathrm{~mm}$. A stereotaxic arm allows motion of the transducer at $\mathrm{x}, \mathrm{y}$, and $\mathrm{z}$ coordinates in micrometric steps to place the probe perpendicular to the arterial axis, i.e., at its largest cross-sectional dimension. The transducer was positioned so that its focal zone was at the center of the artery and the back-scattered echoes from both anterior and posterior walls could be visualized. The radio frequency signal was then displayed on a computer monitor interfaced with the transducer system. Arterial diameter was measured when a "double peak" ultrasound signal of anterior and posterior wall was obtained $(25,26)$. To measure internal diameter, trackers were positioned on the leading edges of echoes. The radio frequency signal was sampled at $100 \mathrm{MHz}$ over 8 bits and wall movements were tracked for $5 \mathrm{~s}$. Software tracker movements were computed at $250 \mathrm{~Hz}$, averaged over the 5-s sampling period and displayed. Finally, instantaneous diameter was determined by multiplying travel time measurements by the approximate speed of sound in tissues $(1.54 \mathrm{~mm} / \mu \mathrm{s})$ and expressed in micrometers. All data processing was performed using software developed by Asulab (Neuchatel, Switzerland) and installed in a $486 / 33 \mathrm{MHz}$ AT computer.

Hemodynamic study. The tip of the pressure transducer was placed in the ascending aorta. A midsternal thoracotomy was performed and the ascending aorta was dissected free. An adapted Doppler probe $(20 \mathrm{MHz}$; Millar Instruments, Inc.) was positioned around the vessel to measure mean (cardiac output minus coronary blood flow) and phasic aortic blood flow. The system was allowed to stabilize for $10 \mathrm{~min}$ before aortic blood flow and pressure were recorded and processed by a microcomputer system (Vectra; Hewlett Packard, Palo Alto, CA) with an analog-digital converter (Metrabyte; Data Translation, Marlboro, MA). All parameters were calculated on a beat-to-beat basis for $30 \mathrm{~s}$ and then averaged.

The basic parameters studied were the systolic, diastolic, and mean arterial blood pressure, the cardiac output, and the heart rate. Total peripheral resistance was determined as the quotient of the mean arterial blood pressure and the cardiac output.

Reactivity of aortic rings. Ring segments of aorta, cleaned of fat and connective tissues, $3 \mathrm{~mm}$ in length, were mounted between two stainless steel wires in 3-ml organ baths containing physiological salt solution of the following composition (in mmol/liter): $135.0 \mathrm{NaCl}$,
$15.0 \mathrm{NaHCO}_{3}, 4.6 \mathrm{KCl}, 1.5 \mathrm{CaCl}_{2}, 1.2, \mathrm{MgSO}_{4}, 11.0$ glucose, 5.0 Hepes. The $\mathrm{pH}$ was adjusted to 7.4 with $\mathrm{NaOH}(1 \mathrm{~mol} / \mathrm{liter})$ and the solution was bubbled with $95 \% \mathrm{O}_{2}$ and $5 \% \mathrm{CO}_{2}$. A physiological salt solution containing $\mathrm{K}^{+} 125 \mathrm{mmol} /$ liter was prepared using the formula described above with $14.4 \mathrm{mmol} /$ liter $\mathrm{NaCl}$ and $125 \mathrm{mmol} / \mathrm{liter}$ $\mathrm{KCl}$. One wire was attached to a fixed support while the second wire was connected to a moveable holder supporting a tension transducer (FT.03; Grass Instrument Co., Quincy, MA) so that isometric force measurements could be collected by a data aquisition system (MP 100; BioPac Systems, Inc., LaJolla, CA) and recorded on a Macintosh Quadra 610 computer (Apple computers, Cupertino, CA) using the Acqknowledge $^{\circledR}$ data acquisition and analysis software (BioPac Systems, Inc.). The artery segments were allowed to recover for $30 \mathrm{~min}$, during which time the physiological salt solution was replaced at 15min intervals. After this recovery period, a 1-g preload, resulting in optimal stretch, was applied to the aortic segments, which were allowed to equilibrate for an additional 90 min (27). Concentrationresponse curves to phenylephrine or angiotensin II were obtained by cumulative addition of phenylephrine or angiotensin II to the bath solution. Data are expressed as milligrams force and as a percentage of $\mathrm{K}^{+}$(125 mmol/liter)-induced contraction.

Plasma angiotensin II measurements. Rats receiving chronic administration of PD123319 $(n=6)$ were compared to six control rats receiving subcutaneous infusion of vehicle solution for 3 wk. For plasma angiotensin measurement, blood was rapidly collected into tubes containing $0.5 \mathrm{ml}$ inhibitor solution (50 mM 1,10-ohenatroline, $125 \mathrm{mM}$ ethylene-diaminetetraacetate, $2 \mathrm{~g} /$ liter neomycin sulfate, $2 \%$ ethanol in water, and $100 \mu \mathrm{mol} /$ liter enalapril) at $4^{\circ} \mathrm{C}$. The samples were immediately centrifuged at $4^{\circ} \mathrm{C}$ and the resulting plasma was stored at $-20^{\circ} \mathrm{C}$ until analyzed. After extraction on phenylsilica columns (Bound Elut pH cartridges; Analytichem International Inc., Harbor City, CA), according to the procedure of Nussberger et al. (28), the dried extracts containing angiotensin were diluted in BSA (5 $\mathrm{g} /$ liter in $0.1 \mathrm{~mol} /$ liter imidazole-HCl buffer, $\mathrm{pH} 7.5$, containing $\mathrm{NaN}_{3}$, $0.2 \mathrm{~g} /$ liter) and assayed in duplicate with radioimmunoassay (E.R.I.A. Diagnostics, Pasteur, France). The amount of angiotensin II in the plasma extracts was estimated from a calibration curve for authentic angiotensin II ranging from 1.5 to $120 \mathrm{pg} / \mathrm{ml}$. Results are expressed as picograms per milliliter.

Morphological study. The descending thoracic aorta was fixed at operating pressure (corresponding to the mean arterial pressure of each rat) in $10 \%$ formaldehyde in saline, removed and embedded in paraffin. Three successive $5-\mu \mathrm{m}$ sagittal sections were treated by specific staining for the various structures in the media. Collagen fibers were stained with Sirius red, elastin with orcein, and nuclei with hematoxylin after periodic acid oxidation (Fig. 1). Morphometric analysis was performed with an automated image processor (NS 15000; Microvision, Evry, France). This processor is based on morphological mathematical principles and is software controlled (29-31). Specific algorithms were used to analyze each of the three stained structures. The images were sent to the processor via a video camera and examined on a video monitor. Luminosity was automatically adjusted by the software to obtain similar levels of contrast, taking into account the total light transmitted by the video camera. The analog image was then digitized. Each elementary point (pixel) was automatically compared to a threshold. If the gray level of the pixel exceeded this threshold, then the pixel was assigned a value of 1 ; otherwise, it was given the numeric value of 0 . Threshold determination was a complex operation involving pixel ensembles. The threshold was determined using the top-hat algorithm to minimize variations in staining and background. This binary image was then processed to eliminate background and artifacts, delineate the zones of interest and the reference zone, and extract and measure the parameters from the various zones of interest. The first algorithm analyzed the mean medial thickness by measuring the distance between the internal and external elastic laminae (70 measurements in each section). The medial elastin network was analyzed in terms of the relative area and mean thickness; the measurements and calculations were made for 12 fields in each sec- 

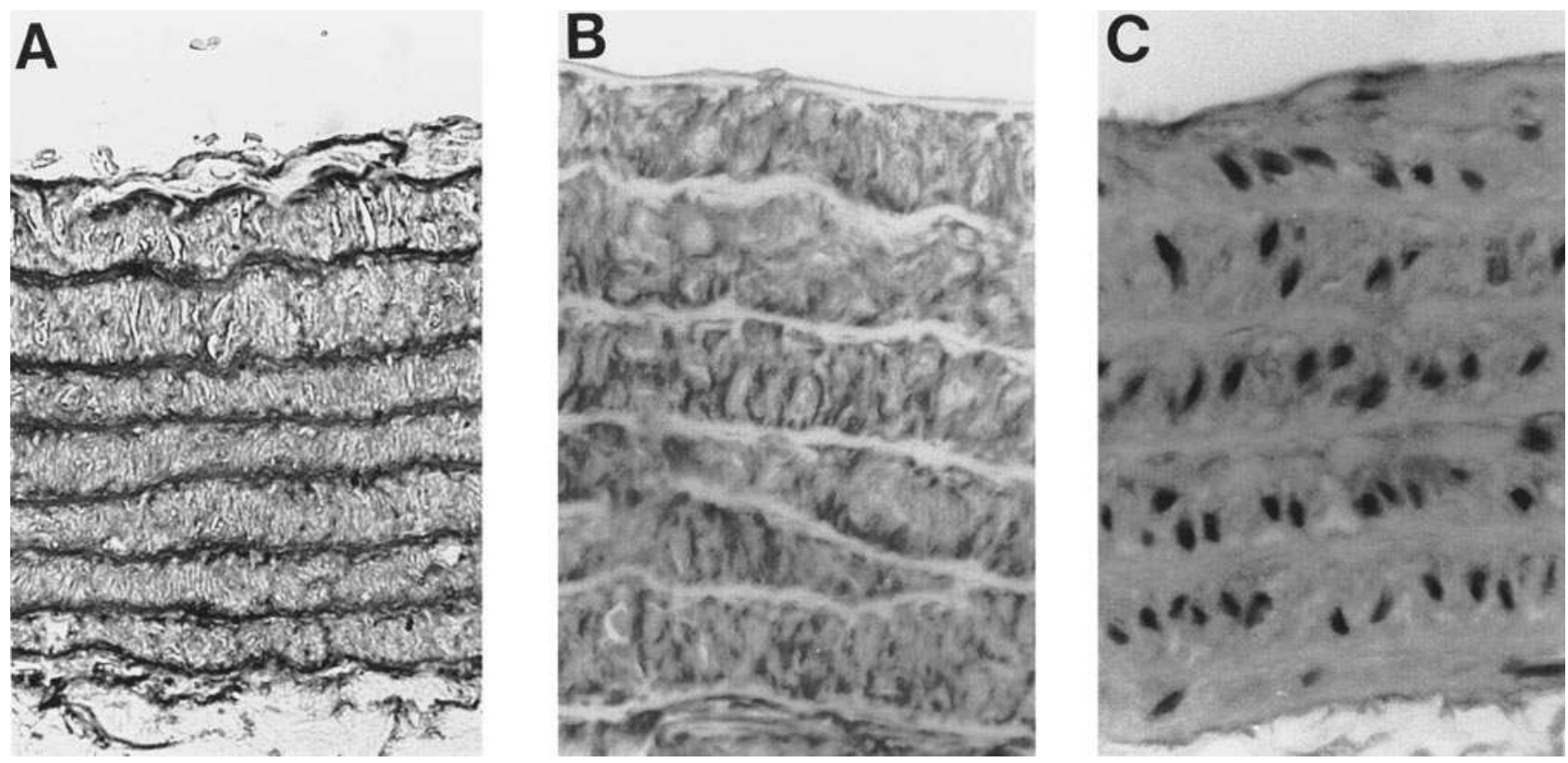

Figure 1. Typical examples of specific staining of the thoracic aorta from the control rats for histomorphometric measurement on elastin $(A)$, collagen $(B)$, and smooth muscle cell nuclei $(C)$.

tion. The second algorithm analyzed the collagen matrix by measuring the relative area/density in 20 contiguous fields in each Sirius redstained section. Elastin and collagen densities were defined as the ratio of the area stained by orcein or Sirius red to the area of the studied field. The total elastin and collagen contents per millimeter of aortic section were calculated as the product of the media surface area per millimeter of longitudinal section (medial thickness $(\mu \mathrm{m}) \times$ $1,000)$ and the elastin and collagen densities, respectively. The third algorithm counted the number of nuclei within 20 fields of about $10,000 \mu \mathrm{m}^{2}$ area on each section and measured the mean area of each nucleus. A two-step procedure (conditional opening, then conditional closing, reference 25) eliminated all particles under a predetermined size. The final result is the images of the nuclei without any "holes" or deformations due to the structuring element (hexagon). The image processor automatically eliminates "borderline" nuclei before measuring the number of nuclei per unit area. As for the elastin and elastin contents, the number of nuclei per millimeter of longitudinal section was calculated from nuclei densities and medial surface area. Repeat measurements were performed, pooled, and averaged for the three algorithms in the corresponding stained sections of the aortic wall media of each rat. The morphological analyses were performed twice by two independent researchers using a single-build protocol.

Statistical analysis (32). Results are expressed as means \pm SEM. Analysis of variance was performed to test differences due to treatments. The differences between groups were evaluated using the Scheffe $f$ test. Nested analysis of variance was performed to compare the morphological results of the thoracic aorta allowing for the within-group variability (field, section, rat).

\section{Results}

The noninvasively measured systolic pressure in the five groups of rats throughout the 3-wk treatment is shown in Fig. 2. Blood pressure was similar in the Ang II and in the Ang II + PD123319 groups and was significantly higher in these two groups than in the control $(P<0.01)$. Furthermore, there was no difference in blood pressure between the control group, the PD123319 group, and the Ang II + PD123319 group.

Table I reports the body weight and the heart weight mea- sured in all groups at the end of the treatment period. Body weight was not affected by treatment in all tested groups; we observed a significant and similar cardiac hypertrophy in rats receiving Ang II and Ang II + PD123319 $(P<0.01$ vs control, NS between Ang II and Ang II + PD123319). In contrast, heart to body weight ratio was significantly reduced in the Ang II + losartan group vs the Ang II group.

Carotid artery diameter. The systolic, diastolic, and mean carotid diameter are shown in Fig. 3. Carotid diameter was significantly larger in rats receiving Ang II as compared with the control group $(P<0.01)$. Treatment with PD123319 alone or with addition of PD123319 and Ang II resulted in a slight but nonsignificant decrease in carotid diameter vs values in the control group. However, the carotid diameter was significantly smaller in Ang II + PD123319 group than in Ang II group $(P<0.01)$. Simultaneous treatment with Ang II and losartan did not significantly affect the carotid diameters despite significant decrease in arterial pressure.

Hemodynamics. The open-chest hemodynamic values measured in the five experimental groups are shown in Table II. The mean arterial blood pressure was significantly higher in

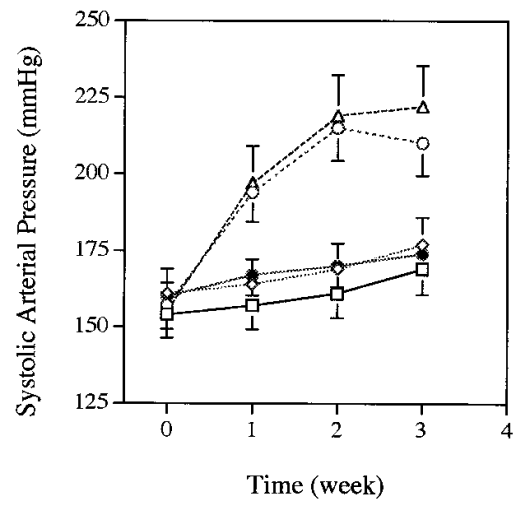

Figure 2. Noninvasive systolic arterial pressure measured by the tail cuff method in the five studied groups (mean \pm SEM). $\square$, control; $\diamond$, PD123319; $\bigcirc$, Ang II; $\Delta$, AngII + PD127319; $\bullet$, Ang II + losartan. 
Table I. Body Weight, Heart Weight, and Heart/Body Weight Ratio (Mean士SEM)

\begin{tabular}{lccccc}
\hline & Control & Ang II & Ang II + PD123319 & PD123319 & Ang II + losartan \\
\hline & $n=20$ & $n=12$ & $n=12$ & $n=12$ & $n=12$ \\
Body weight $(\mathrm{g})$ & $427 \pm 8$ & $417 \pm 7$ & $431 \pm 11$ & $421 \pm 6$ & $391 \pm 14$ \\
Height weight (mg) & $1159 \pm 27$ & $1316 \pm 48^{*}$ & $1295 \pm 31^{*}$ & $1231 \pm 41$ & $1085 \pm 75$ \\
Heart/body weight (mg/g) & $2.69 \pm 0.05$ & $3.12 \pm 0.11^{\ddagger}$ & $3.00 \pm 0.05^{*}$ & $2.95 \pm 0.13$ & $2.71 \pm 0.17^{\S}$ \\
\hline
\end{tabular}

${ }^{*} P<0.05$ vs control group $;{ }^{\ddagger} P<0.01$ vs control group $;{ }^{\S} P<0.05$ vs Ang II group.

Ang II and in Ang II + PD123319 groups than in the control (by 33 and $30 \%$, respectively, $P<0.01$ ). PD123319 alone did not modify the arterial pressure as compared with the control group, while rats receiving infusion of Ang II + PD123319 had the same blood pressure as animals receiving Ang II alone. In contrast, losartan antagonized the Ang II-induced hypertension: arterial pressure and peripheral resistance were even significantly lower in the Ang II + losartan group than in the control $(P<0.01)$. Cardiac output and heart rate were similar in all studied groups. Total peripheral resistance was significantly larger in Ang II and in Ang II + PD123319 than in the control group (by 26 and by $39 \%$, respectively, $P<0.05$ ). Infusion of PD123319 alone did not modify the peripheral resistance vs control animals.

Aortic reactivity and plasma angiotensin II. Chronic treatment with PD123319 did not significantly affect the aortic maximal response to $\mathrm{KCl}(125 \mathrm{mmol} / \mathrm{liter}, 2.37 \pm 0.25 \mathrm{~g}$ and $2.46 \pm 0.12 \mathrm{~g}$ in the control and PD123319 group, respectively). In the same way, the response to increasing concentration of phenylephrine was not effected by chronic treatment with PD123319 (E max: 2.24 $\pm 0.22 \mathrm{~g}$ and 2.44 $\pm 0.11 \mathrm{~g} ; \mathrm{EC}_{50}$ $0.12 \pm 0.024 \mu \mathrm{M}$ and $0.09 \pm 0.023 \mu \mathrm{M}$ in the control group and in the PD123319 group, respectively, NS). The Fig. 4 shows the in vitro effect of increasing concentrations of Ang II on aortic rings from control and chronic PD123319-treated rats under basal conditions and after acute addition of losartan $(10 \mu \mathrm{mol} /$ liter) or PD123319 (10 $\mu \mathrm{mol} / \mathrm{liter})$ in the organ chamber. The aortic contractile response to Ang II was not significantly effected by chronic treatment with PD123319. Acute addition of losartan in the organ chamber completely blocked the Ang IIinduced contraction in both groups. Finally, acute addition of PD123319 in the organ chamber did not modify the aortic ring response to Ang II in either control or PD123319 chronically treated rats.

Plasma angiotensin II levels were not affected by chronic treatment with PD123319: Ang II plasma concentration was $72 \pm 4 \mathrm{pg} / \mathrm{ml}$ in the control group and $78 \pm 3 \mathrm{pg} / \mathrm{ml}$ in rats chronically treated with PD123319.

Histomorphometry. Results of histomorphometric analysis are given in Table III. The aortic media thickness and crosssectional area were significantly greater in Ang II and in Ang II + losartan than in control rats (by 24 and $34 \%$ in the Ang II group, $P<0.01$, and by 13 and $18 \%$, respectively, $P<0.05)$. In contrast, we did not observe aortic media hypertrophy in either the Ang II + PD123319 or the PD123319 groups. Treatment with Ang II + losartan did not significantly reduce the aortic media thickness and cross-sectional area vs their respective values in the Ang II group.

The aortic elastin and collagen contents were similarly increased in the Ang II group vs the control (by 24 and 35\%, re-

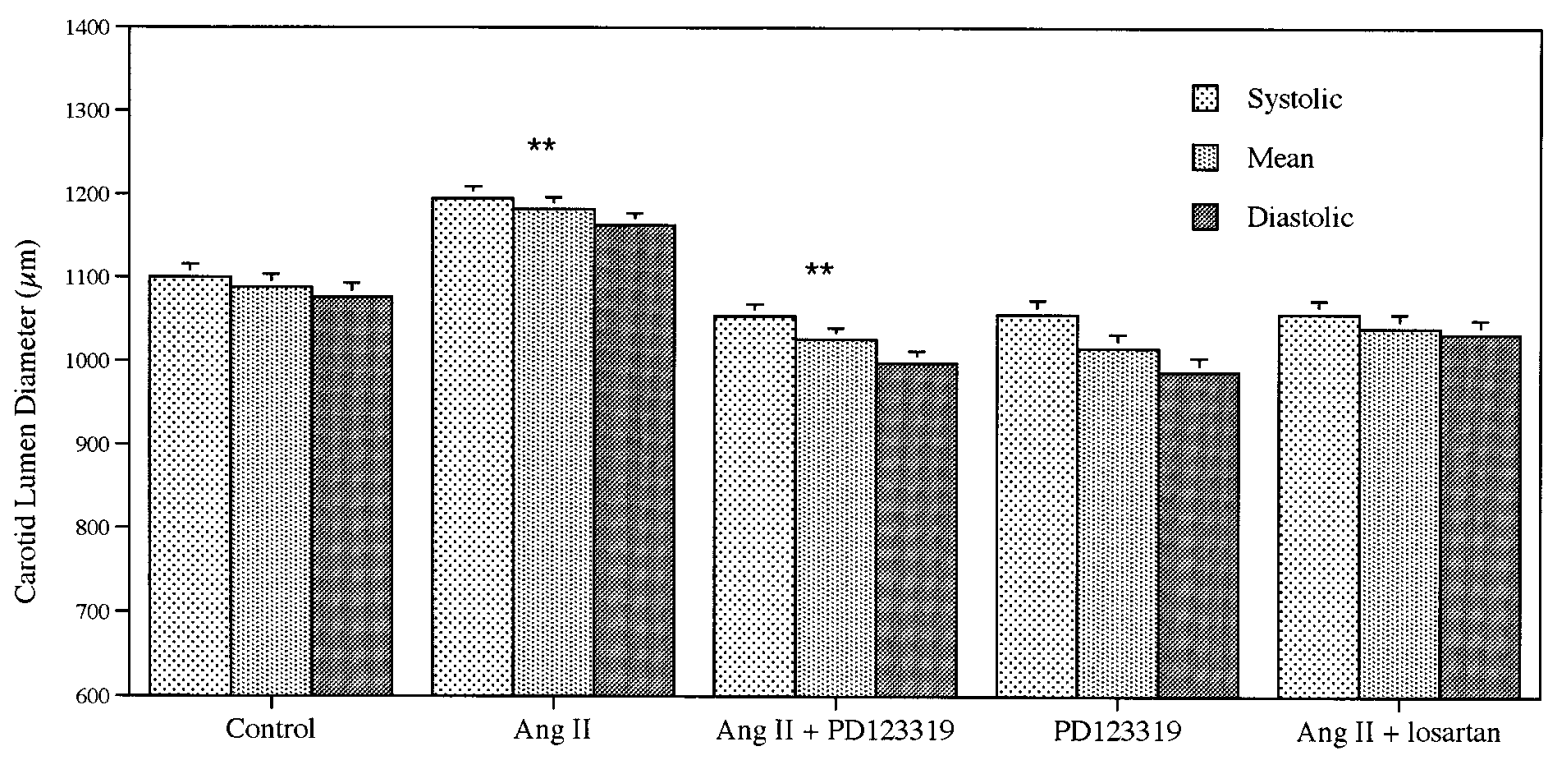

Figure 3. Systolic, diastolic, and mean carotid lumen diameter measured by noninvasive ultrasounds in the five studied groups (mean \pm SEM). ** $P<0.01$ vs control. 
Table II. Hemodynamic Values Recorded in Anesthetized Opened-chest Rats

\begin{tabular}{|c|c|c|c|c|c|}
\hline & Control & Ang II & Ang II + PD123319 & PD123319 & Ang II + losartan \\
\hline & $n=20$ & $n=12$ & $n=12$ & $n=12$ & $n=12$ \\
\hline Systolic pressure $(\mathrm{mmHg})$ & $137 \pm 3$ & $170 \pm 7 *$ & $169 \pm 7 *$ & $136 \pm 8$ & $107 \pm 3^{* \frac{\dot{T}}{4}}$ \\
\hline Diastolic pressure $(\mathrm{mmHg})$ & $102 \pm 2$ & $136 \pm 5^{*}$ & $134 \pm 6^{*}$ & $101 \pm 8$ & $81 \pm 4 * \S$ \\
\hline Mean pressure $(\mathrm{mmHg})$ & $114 \pm 2$ & $154 \pm 6^{*}$ & $151 \pm 6^{*}$ & $114 \pm 9$ & $93 \pm 4 * \S$ \\
\hline Cardiac output (ml/min) & $78 \pm 3$ & $81 \pm 5$ & $77 \pm 7$ & $84 \pm 9$ & $88 \pm 3$ \\
\hline Heart rate (per min) & $448 \pm 9$ & $420 \pm 12$ & $448 \pm 14$ & $419 \pm 12$ & $437 \pm 11$ \\
\hline \multicolumn{6}{|l|}{ Total peripheral resistance } \\
\hline$\left(10^{3}\right.$ dyn. s. $\left.\mathrm{cm}^{-5}\right)$ & $123 \pm 4$ & $156 \pm 9 \|$ & $173 \pm 16$ & $111 \pm 12$ & $86 \pm 6^{* \neq}$ \\
\hline
\end{tabular}

${ }^{*} P<0.01$ vs control group; ${ }^{\ddagger} P<0.001$ vs Ang II group; ${ }^{\S} P<0.01$ vs Ang II group; $\| P<0.05$ vs control group.

spectively, $P<0.05)$ and remained normal in the Ang II + PD123319 and PD123319 groups. There was no difference in elastin and collagen contents in aortae from Ang II and Ang II + losartan groups. Likewise, we measured larger smooth muscle cell nuclei size in the Ang II group as compared with the control group (by 29 and $25 \%$, respectively, $P<0.05$ ), indicating smooth muscle cell hypertrophy and hyperplasia in rats receiving Ang II alone. In the Ang II + losartan group, we observed a similar increase in smooth muscle cell nuclei size compared with the Ang II group, whereas the number of smooth muscle cell nuclei remained normal. In rats receiving Ang II + PD123319 or PD123319 alone, the number and the size of the aortic smooth muscle cells remained at the baseline level.

\section{Discussion}

The main findings of the present study obtained in a model of Ang II-induced hypertension are that chronic administration of a selective antagonist of AT2 subtype Ang II receptor (PD123319, $30 \mathrm{mg} / \mathrm{kg}$ per d) (a) had no effect on hemodynamic parameters and especially on the systemic resistance, and $(b)$ did not affect the cardiac hypertrophy, but ( $c$ ) antagonized the effect of Ang II on smooth muscle cell growth and extra cellular matrix expression despite elevated blood pressure, as indicated by the inhibition of the increase in carotid lumen diameter, the absence of aortic medial hypertrophy, and especially of increase in medial collagen content.

In contrast, chronic selective blockade of AT1 subtype Ang II receptor (losartan, $10 \mathrm{mg} / \mathrm{kg}$ per d) antagonized the hemodynamic effects of Ang II, but did not significantly affect the Ang II-induced vascular hypertrophy.

Furthermore, in an additional set of experiments, we observed that chronic administration of PD123319 in normotensive rats did not affect the Ang II plasma level or the aortic ring reactivity to angiotensin II, indicating that a blockade of AT2 subtype receptor for $3 \mathrm{wk}$ did not affect angiotensin II production and AT1 receptors. Macari et al. (33) reported that infusion of PD123319 at doses of $30 \mathrm{mg} / \mathrm{kg}$ per $\mathrm{d}$ in the rat results in plasma levels around $200 \mathrm{nmol} / \mathrm{liter}$. Since the $50 \%$ infective concentration of PD123319 for the AT2 receptor is $\sim 17 \mathrm{nmol} / \mathrm{liter}$, infusion of $30 \mathrm{mg} / \mathrm{kg}$ per $\mathrm{d}$ of PD123319 should result in an effective AT2 blockade without affecting the AT1 receptor. In agreement with our present hemody-

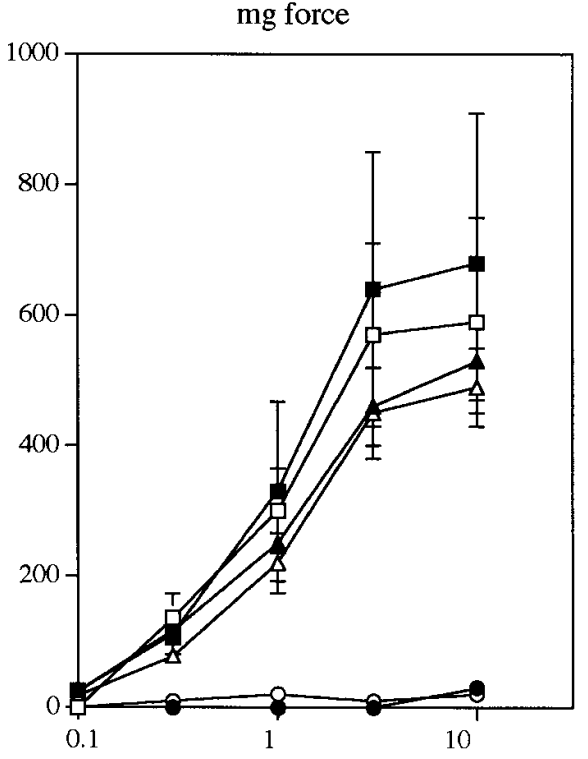

Angiotensin II $(\mu \mathrm{mol} / \mathrm{L})$

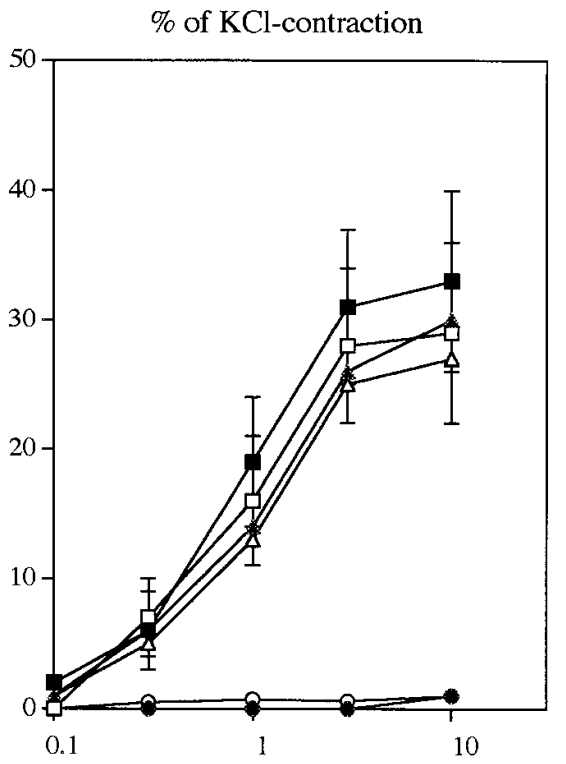

Angiotensin II $(\mu \mathrm{mol} / \mathrm{L})$
Figure 4. Effects of chronic blockade of AT2 angiotensin II receptors by PD123319 $(30 \mathrm{mg} / \mathrm{kg}$ per $\mathrm{d}$ for $3 \mathrm{wk}$ ) on responses to angiotensin II in aortic rings. Acute blockade of AT1 or AT2 receptors was obtained by incubation with losartan $(10 \mu \mathrm{mol} /$ liter $)$ or PD123319 (10 $\mu \mathrm{mol} /$ liter $)$. $\square$, control; $\mathbf{\square}$, PD123319; $\bigcirc$, control + losartan (acute); ๑, PD123319 + losartan (acute); $\Delta$, control + PD123319; $\boldsymbol{\Lambda}$, PD123319 + PD123319 (acute). 
Table III. Histomorphometric Values Measured in the Thoracic Aorta

\begin{tabular}{|c|c|c|c|c|c|}
\hline & Control & Ang II & Ang II + PD123319 & PD123319 & Ang II + losartan \\
\hline & $n=20$ & $n=12$ & $n=12$ & $n=12$ & $n=12$ \\
\hline Cross-sectional area $\left(\mathrm{mm}^{2}\right)$ & $0.90 \pm 0.06$ & $1.18 \pm 0.06^{*}$ & $0.98 \pm 0.04^{\ddagger}$ & $0.84 \pm 0.08$ & $1.04 \pm 0.04^{\S}$ \\
\hline Media thickness $(\mu \mathrm{m})$ & $119 \pm 3$ & $145 \pm 7^{\|}$ & $122 \pm 3^{\ddagger}$ & $113 \pm 7$ & $132 \pm 7^{\S}$ \\
\hline \multicolumn{6}{|l|}{ Collagen content } \\
\hline$\left(10^{3} \mu \mathrm{m}^{2} / \mathrm{mm}\right.$ section $)$ & $12.9 \pm 2$ & $17.1 \pm 0.9^{\S}$ & $9.8 \pm 1.1^{\text {पा }}$ & $13.6 \pm 1.5$ & $17.8 \pm 1.4^{\S}$ \\
\hline \multicolumn{6}{|l|}{ Elastin content } \\
\hline (10 $\mu^{3} \mathrm{~m}^{2} / \mathrm{mm}$ section $)$ & $25.9 \pm 1.6$ & $31.5 \pm 1.3^{\S}$ & $26.7 \pm 1.1^{\ddagger}$ & $27.8 \pm 1.8$ & $33.7 \pm 2.2^{\|}$ \\
\hline \multicolumn{6}{|l|}{ Nuclei number } \\
\hline (per mm section) & $501 \pm 27$ & $632 \pm 50^{\S}$ & $514 \pm 43$ & $499 \pm 35$ & $450 \pm 25^{\ddagger}$ \\
\hline Nuclei size $\left(\mu \mathrm{m}^{2}\right)$ & $7.1 \pm 0.2$ & $8.9 \pm 0.7^{\S}$ & $8.2 \pm 0.4$ & $7.8 \pm 0.7$ & $9.1 \pm 0.7 *$ \\
\hline
\end{tabular}

${ }^{*} P<0.001$ vs control group; ${ }^{\ddagger} P<0.05$ vs Ang II group; ${ }^{\circledR} P<0.05$ vs control group; $\| P<0.01$ vs control group; ${ }^{\text {q }} P<0.01$ vs Ang II group.

namic results, the same group reported that arterial pressure was unaffected by infusion of PD123319 for doses as high as $100 \mu \mathrm{g} / \mathrm{kg}$ per min (i.e., $144 \mathrm{mg} / \mathrm{kg}$ per d).

Considerable effort has been directed toward determining whether Ang II, acting through AT2 receptors plays a role in the control of cardiovascular hemodynamics (34). Our present results and earlier studies demonstrate that Ang II-induced contraction of aortic rings was antagonized by losartan, but was unaffected by the AT2 antagonist PD123177 at doses as high as $10^{-4} \mathrm{M}$. Likewise, the pressor effect of intravenously injected Ang II in the rat can be antagonized by losartan but is unaffected by PD123177 at doses up to $100 \mathrm{mg} / \mathrm{kg}$. Our present study confirms that chronic blockade of AT2 receptors do not affect the control of cardiovascular hemodynamics (arterial pressure, cardiac output, heart rate) either in normotensive rats or in Ang II-induced hypertensive rats. Furthermore, in the present study, plasma angiotensin II level and aortic reactivity to Ang II was not affected after chronic AT2 receptor blockade. The plasma angiotensin II levels were very similar to those previously reported under control conditions in normotensive rats (35).

The role of Ang II as a growth factor has been demonstrated in a number of studies using fibroblast (36), adrenal cortical (37), vascular smooth muscle (38), or cardiac cells (39). In each case, nonspecific Ang II receptor antagonists inhibited the response to Ang II. It appears, however, that Ang IIinduced hypertrophy only occurs in the presence of additional growth factors and may act indirectly through the release of substances such as transforming growth factor $\beta$ endothelin, and platelet-derived growth factor A-chain (40-42). It appears that the growth response to Ang II in cultured vascular smooth muscle cells is mediated by AT1 subtype receptors. In rat aortic smooth muscle cells, administration of Ang II $\left(10^{-7} \mathrm{M}\right)$ to quiescent cells induced hypertrophy and hyperplasia after a 24-h incubation; both responses were blocked by losartan $\left(10^{-5}\right)(43)$. In contrast to its proliferating affect on vascular smooth muscle cells, Ang II may exert antiproliferative actions on vascular endothelial cells. A previous study by Stoll et al. (44) demonstrated that the angiotensin AT2 receptor mediates inhibition of cultured endothelial cells and, in a recent study by Yamada et al. (45), AT2 receptors favored apoptosis in a rat pheochromocytoma cell line.

In vivo, the role of the AT1 subtype receptor in the Ang IIinduced vascular hypertrophy has been also extensively docu- mented. The vascular hypertrophic response to Ang II was demonstrated by morphometric analysis of vessels after chronic infusion of low doses of Ang II (46); in agreement, we reported that renovascular hypertension induced aortic hypertrophy and hyperplasia, both reversed by chronic treatment with angiotensin-converting enzyme inhibitor (47). Recently, Morishita et al. (48) using gene transfer strategy, demonstrated that an increase in local expression of vascular angiotensinconverting enzyme can directly cause vascular hypertrophy independently of systemic factors and hemodynamic effects supporting a role for autocrine/paracrine affect of Ang II on vascular cell growth. We also previously reported that, in spontaneously hypertensive rats receiving angiotensin-converting enzyme inhibitor for $8 \mathrm{wk}$, arterial hypertrophy and collagen content could be specifically related to aortic tissue angiotensin-converting enzyme activity independently of hemodynamic factors (49). Finally, Ang II has angiogenic affects expressed in the rabbit cornea (50) and the chorioallantoic membrane of the chick embryo (51). Le Noble et al. (51) reported that, in the chorioallantoic membrane assay, the increase in microvascular density induced by Ang II is blocked by an AT2 subtype receptor antagonist. However, the natural ligand for the chick is Val 3-Ang II instead of the Ile5-Ang II for mammals used in Le Noble's study; therefore, this result needs further investigation. In chronic Ang II infusion studies in rats, losartan reversed the Ang II-induced hypertension in the conscious rat (52), but no analysis of the vasculature was performed. In a preliminary study, we reported that losartan (10 mg/kg per d) reversed Ang II-induced hypertension, but not aortic wall hypertrophy (53). This was also observed in the present work. Finally, in an experimental model of neointimal formation by carotid artery injury in the rat, Nakajima et al. (21) suggested that the AT2 receptor exerts an antiproliferative affect on the neointimal formation. However, in these in vivo experiments, the media cross-sectional area was differently affected than the neointimal formation: AT2 receptor expression vector-transfected arteries evidenced marked media hypertrophy and decreased neointimal proliferation, whereas treatment with PD123319 did not affect the neointimal formation, but reduced medial hypertrophy in AT2 receptor expression vector-transfected arteries. Therefore, although conclusive evidence supports the role of the AT1 receptor in smooth muscle cell growth, the in vivo role of the AT2 receptor is not clearly defined. 
In the present study, observed increases in both in vivo carotid diameter and aortic section media thickness in the Ang II group indicate an arterial growth effect of chronic infusion of angiotensin II. In as much as blood pressure was increased in Ang II-infused rats, the increase in the carotid lumen diameter observed in the Ang II group could be related to hypertension, independently on direct affect of Ang II on the vessel growth (54). However, the addition of AT2 receptor antagonist to angiotensin II in the Ang II + PD123319 group antagonized both increases in carotid lumen diameter and in aortic wall thickness, but did not affect the increase in arterial pressure. Taken together, these results suggest that the carotid lumen enlargement and the aortic hypertrophy in the Ang II group resulted from growth processes mediated through AT2 subtype receptor.

The role of the AT2 receptor in cell growth has been established in various cell types, including lymphocytes (55), astrocytes (56), neuroblastoma cells (57), and possibly smooth muscle cells (20). Recently, Brilla et al. (58) reported, in cultured adult rat cardiac fibroblasts, that Ang II stimulates collagen synthesis by both AT1 and AT2 receptors and that Ang II inhibition of collagenase activity is specifically mediated by the AT2 subtype receptor. This latter finding could account for our present results showing an increase in aortic collagen content in rats receiving Ang II, and unaffected collagen wall content when AT2 receptors are blocked. Interestingly, Morishita et al. (48), using an in vivo model of rats transfected with angiotensin-converting enzyme expression vector in the carotid wall, which resulted in an increase in local generation of Ang II, demonstrated that subcutaneous injection of high doses of losartan $(20 \mathrm{mg} / \mathrm{kg}$ per d) significantly reduced, but did not restore, normal levels of DNA synthesis in the carotids of transfected animals $(P<0.05$ vs control). This latter result suggests that a part of the growth affect of Ang II could be mediated by non-AT1 receptors.

In conclusion, we tried in the present in vivo work to dissociate the angiotensin II-induced hypertension from vascular hypertrophy. We confirmed that chronic pharmacological blockade of AT2 subtype Ang II receptors had no systemic hemodynamic effect and did not affect the hypertension-induced cardiac hypertrophy. Furthermore, chronic blockade of AT2 receptors did not affect the plasma level of angiotensin II and the vascular reactivity to angiotensin II mediated by the AT1 receptor. The present study also showed that chronic blockade of AT2 receptors antagonized the vascular growing effects related to long term Ang II injection, whereas blockade of AT1 receptors did not. We therefore suggest that the vasotrophic effect of Ang II is at least partially mediated via AT2 receptor subtype in this experimental model of hypertension.

\section{Acknowledgments}

This work was partly supported by a grant from Institut de Recherche International Servier INSERM 94093.

\section{References}

1. Naftilan, A.J., R.E. Pratt, C.S. Eldridge, and V.J. Dzau. 1989. Angiotensin II induces c-fos expression in smooth muscle cells via transcriptional control. Hypertension (Dallas). 13:706-711.

2. Katz, A.M. 1990. Angiotensin II: hemodynamics regulator aortic growth factor? J. Mol. Cell. Cardiol. 22:739-747.

3. Geistefer, A.A.T., M.J. Peach, and G.K. Owens. 1990. Angiotensin II induces hypertrophy but not hyperplasia of cultured rat aortic smooth muscle cells. Circ. Res. 62:749-756.

4. Paquet, J.L., M. Bandomin-Legros, G. Brunelle, and P. Meyer. 1990. Angiotensin II-induced proliferation of aortic myocytes in spontaneously hypertensive rats. J. Hypertens. 8:565-572.

5. Lyall, F.M., J.J. Morton, F. Lever, and E.J. Cragoe. 1988. Angiotensin II activates $\mathrm{Na}-\mathrm{H}$ exchanges and stimulates growth in cultured smooth muscle cells. J. Hypertens. 6(Suppl. 4):438-441.

6. Aceto, J.F., and K.M. Baker. 1990. (SarI)angiotensin II receptor-mediated stimulation of protein synthesis in chick heart cells. Am. J. Physiol. 258: 806-813.

7. de Gasparo, M., A. Husain, W. Alexander, K.J. Catt, A.T. Chiu, M. Drew, T. Goodfriend, J.W. Harding, T. Inagami, and P.B. Timmermans. 1995. Proposed update of angiotensin receptor nomenclature. Hypertension (Dallas). 25:924-927.

8. Koepke, J.P., P.R. Bovy, E.G. McMahon, G.M. Olins, D.B. Reitz, K.S. Salles, J.R. Schuh, A.J. Trapani, and E.H. Blaine. 1990. Central and peripheral actions of a nonpeptide angiotensin II receptor antagonist. Hypertension (Dallas). 15:841-847.

9. Smits, G.J., J.P. Koepke, and E.H. Blaine. 1991. Reversal of low dose angiotensin hypertension by angiotensin receptor antagonists. Hypertension (Dallas). 18:17-21.

10. Tofovic, S.P., A.S. Pong, and E.K. Jackson. 1991. Effect of angiotensin subtype 1 and subtype 2 receptor antagonists in normotensive versus hypertensive rats. Hypertension (Dallas). 18:774-782.

11. Wong, P.C., S.D. Hart, A.L. Zaspel, A.T. Chiu, R.J. Ardecky, R.D. Smith, and P.B.M.W.M. Timmermans. 1990. Functional studies of nonpeptide angiotensin II receptor subtype-specific ligands: DuP 753 (AII-1) and PD123177 (AII-2). J. Pharmacol. Exp. Ther. 255:584-592.

12. Wong, P.C., S.D. Hart, J.V. Duncia, and P.B.M.W.M. Timmermans. 1991. Nonpeptide angiotensin II receptor antagonists: studies with DuP 753 and EXP3174 in dogs. Eur. J. Pharmacol. 202:323-330.

13. Tsutsumi, K., C. Strömberg, M. Viswanathan, and J.M. Saavedra. 1991. Differential development of angiotensin II receptor subtypes in the rat brain. Endocrinology. 129:1075-1082.

14. Millan, M.A., P. Carvallo, S.I. Izumi, S. Zemel, K.J. Catt, and G. Aguilera. 1989. Novel sites of expression of functional angiotensin II receptors in the late gestation fetus. Science (Wash. DC). 244:1340-1342.

15. Sechi, L.A., C.A. Griffin, and M. Schambelan. 1994. The cardiac reninangiotensin system in STZ-induced diabetes. Diabetes. 43:1180-1184.

16. Nio, Y., H. Matsubara, S. Murasawa, M. Kanasaki, and M. Indana. 1995. Regulation of gene transcription of angiotensin II receptor subtypes in myocardial infarction. J. Clin. Invest. 95:46-54.

17. Wiemer, G., B.A. Scholkens, A. Wagner, H. Heitsch, and W. Linz. 1993 The possible role of angiotensin II subtype AT2 receptors in endothelial cells and ischemic rat hearts. J. Hypertens. 11(Suppl. 5):234-235.

18. Wu, J., D. Edwards, and K.H. Berecek. 1994. Changes in renal angiotensin II receptors in spontaneously hypertensive rats by early treatment with the angiotensin-converting enzyme inhibitor captopril. Hypertension (Dallas). 23:819-822.

19. Dzau, V.J., G.H. Gibbons, and R.E. Pratt. 1991. Molecular mechanisms of vascular renin-angiotensin system in myointimal hyperplasia. Hypertension (Dallas). 18(Suppl. 4):100-105.

20. Janiak, P., A. Pillon, J.F. Prost, and J.P. Vilaine. 1992. Role of angiotensin subtype 2 receptor in neointima formation after vascular injury. Hypertension (Dallas). 20:737-745.

21. Nakajima, M., H.G. Hutchinson, M. Fujinaga, W. Hayashida, R. Morishita, L. Zhang, M. Horiuchi, R.E. Pratt, and V.J. Dzau. The angiotensin II type 2 (AT2) receptor antagonizes the growth effect of the AT1 receptor: gainof-function study using gene transfer. Proc. Natl. Acad. Sci. USA. 92:1066310667.

22. Benessiano, J., B.I. Lévy, and J.B. Michel. 1985. Instantaneous aortic blood flow measurements with range gated Doppler flowmeter in anesthetized rat. J. Pharmacol. Methods. 14:99-110.

23. Levy, B.I., M. Duriez, M. Phillipe, P. Poitevin, and J.B. Michel. 1994. Effect of chronic dihydropyridine on the large arterial wall of spontaneously hypertensive rats. Circulation. 90:3024-3033.

24. Tardy, Y., J.J. Meister, F. Perret, H.R. Brunner, and M. Arditi. 1991. Non invasive estimate of the mechanical properties of peripheral arteries from ultrasonic and photoplethysmographic measurements. Clin. Phys. Physiol. Meas. 12:39-54.

25. Pignoli, P., E. Tremoli, A. Poli, P. Oreste, and R. Paoleti. 1986. Intimal plus media thickness of the arterial wall: a direct measurement with ultrasound imaging. Circulation. 74:1399-1406.

26. Laurent, S., X. Girerd, J.J. Mourad, P. Lacolley, L. Beck, P. Boutourye, J.P. Mignot, and M.E. Safar. 1994. Elastic modulus of the radial artery wall material is not increased in patients with essential hypertension. Arterioscler. Thromb. 14:1223-1231.

27. Henrion, D., J.M. Chillon, F. Muller, C. Capdeville-Atkinson, M. Vinceneux-Feugier, and J. Atkinson. 1991. Chronic treatment with the angiotensin I converting enzyme inhibitor, perindopril, restores in vitro carbachol-induced vasorelaxation in a rat model of vascular calcium overload. Br. J. Pharmacol. 104:966-972. 
28. Nussberger, J., D.B. Brunner, B. Waeber, and H.R. Brunner. 1985. True versus immunoreactive angiotensin II in human plasma. Hypertension (Dallas). 7(Suppl. I)1-7.

29. Serra, J. 1982. Image Analysis and Mathematical Morphology. Academic Press Inc. London. 31-52.

30. Salzmann J.L, M. Azizi, J.B. Michel, and J.P. Camilleri. 1987. Aortic media structural parameters study using mathematical morphology processor analysis. Acta Stereol. 6:437-441.

31. Sans M., and A. Moragas. 1993. Mathematical morphologic analysis of the aortic medial structure. Analytical. Quant. Cytol. Histol. 15:93-100.

32. Zar, J.H. 1984. Biostatistical Analysis. Prentice Hall, Englewood Cliffs, NJ.

33. Macari, D., S. Whitebread, F. Cumin, M. De Gasparo, and N. Levens. 1994. Renal actions of the angiotensin AT2 receptor ligands CGP 42112 and PD 123319 after blockade of the renin-angiotensin system. Eur. J. Pharmacol. 259:27-36.

34. de Gasparo M., S. Bottari, and N.R. Levens. 1995. Characteristics of Angiotensin II receptors and their role in cell and organ physiology. In Hypertension Pathophysiology, Diagnosis and Management. 2nd Ed. J.H. Laragh and B.M. Brenner, editors. Raven Press Ltd., New York. 1695-1720.

35. Campbell, D.J., A.C. Lawrence, A. Towrie, A. Kladis, and A.J. Valentijn. 1991. Differential regulation of angiotensin peptide levels in plasma and kidney of the rat. Hypertension (Dallas). 18:763-773.

36. Ganten, D., P. Schelling, R.M. Flugel, and H. Fischer. 1975. Effects of angiotensin and the angiotensin antagonist P113 on iso-renin and cell growth in 3T3 mouse cells. IRCS (Int. Res. Commun. Syst.) Med. Sci. 3:327.

37. Gill, G.N., C.R. Ill, and M.H. Simonian. 1977. Angiotensin stimulation of bovine adrenocortical cell growth. Proc. Natl. Acad. Sci. USA. 74:5569-5573.

38. Owens, G.K. 1985. Differential effects of antihypertensive drug therapy on vascular smooth muscle cell hypertrophy, hyperploidy and hyperplasia in the spontaneously hypertensive rat. Circ. Res. 56:525-536.

39. Khairallah, P.A., A.L. Robertson, and D. Davila. 1972. Effects of angiotensin II on DNA, RNA and protein synthesis. In Hypertension. J. Genest and E. Koiw, editors. Springer-Verlag, Germany. 212-220.

40. Stouffer, G.A., and G.K. Owens. 1992. Angiotensin II-induced mitogenesis of spontaneously hypertensive rat-derived cultured smooth muscle cells is dependent on autocrine production of transforming growth factor $\beta$. Circ. Res. 70:820-828.

41. Hahn, A.W.A., S. Regenass, T.J. Resink, F. Kern, F. Ferracin, and F.R. Buhler. 1991. Angiotensin II induction of of growth factors and endothelin 1 expression in vascular smooth muscle cells. J. Hypertens. 10(Suppl. 4):448.

42. Gibbons, G.H., R.E. Pratt, and V.J. Dzau. 1992. Vascular smooth muscle cell hypertrophy versus hyperplasia. Autocrine transforming growth factor b1 expression determines growth response to angiotensin II. J. Clin. Invest. 90: $456-461$

43. Chiu, A.T., W.A. Roscoe, D.E. McCall, and P.B.M.W.M. Timmermans. 1991. Angiotensin II-1 receptors mediate both vasoconstriction and hypertrophic responses in rat aortic smooth muscle cells. Receptor. 1:133-140.
44. Stoll, M., M. Steckelings, M. Paul, S.P. Bottari, R. Metzger, and T. Unger. 1995. The angiotensin AT2-receptor mediates inhibition of cell proliferation in coronary endothelial cells. J. Clin. Invest. 95:651-657.

45. Yamada, T., M. Horichiu, and V.J. Dzau. 1996. Angiotensin II type 2 receptor mediates programmed cell death. Proc. Natl. Acad. Sci. USA. 93:156160

46. Lever, A.F., F. Lyall, J.J. Morton, and B. Folkow. 1992. Angiotensin II vascular structure and blood pressure. Kidney Int. 41(Suppl. 37):51-55.

47. Levy, B.I., J.B. Michel, J.L. Salzmann, M. Azizi, P. Poitevin, M.E. Safar, and J.P. Camilleri. 1988. Effects of chronic inhibition of converting enzyme on the mechanical and structural properties of arteries in rat renovascular hypertension. Circ. Res. 63:227-239.

48. Morishita, R., G.H. Gibbons, K.E. Ellison, W. Lee, L. Zhang, H. Yu, Y. Kaneda, T. Ogihara, and V.J. Dzau. 1995. Evidence for direct local effect of angiotensin II in vascular hypertrophy. in vivo gene transfer of angiotensin converting enzyme. J. Clin. Invest. 95:978-984

49. Albaladejo, P., H. Bouaziz, M. Duriez, P. Gohlke, B.I. Levy, M.E. Safar, and A. Benetos 1994. Angiotensin converting enzyme inhibition prevents the increase in aortic collagen. Hypertension (Dallas). 23:74-82.

50. Fernandez, L.A. 1990. Inhibiting of tumor growth with an antagonist of the renin angiotensin system. U.S. Patent No 4.898.732. Feb 6, 1990.

51. Le Noble, F.A., N.H. Schreurs, H.W. van Straaten, D.W. Smith, H. Rogg, and H.A. Strujker-Boudier. 1993. Evidence for a novel angiotensin II receptor involved in chick embryo chrorioallantoic membrane. Am. J. Physiol. 264:460-465.

52. Gorbea-Oppliger, V.J., N.L. Kanagy, and G.D. Fink. 1992. Losartan (DUP 753) reverses angiotensin-induced hypertension in conscious rats. FASEB J. 6:A1810.

53. Biset, T., J. Benessiano, M. Duriez, E. Mathieu, and B.I. Levy. 1993. Trophic effect of angiotensin II on the structure and function of large arteries in rats. Circulation. 88(Suppl. I):2280.

54. Caputo, L., A. Tedgui, and B.I. Levy. 1995. Control of the vasomotor tone by local renin-angiotensin system in normotensive and spontaneously hypertensive rats. Circ. Res. 77:303-309.

55. Kunert-Radek, J., H. Stepien, J. Komorowski, and M. Pawlikowski. 1994. Stimulatory effect of angiotensin II on the proliferation of mouse spleen lymphocytes in vitro is mediated via both types of angiotensin II receptors. Biochem. Biophys. Res. Comm. 198:1034-1039.

56. Jaiswal, N., E.A. Tallant, D.I. Diz, M.C. Khosla, and C.M. Ferrario. 1991. Subtype 2 angiotensin receptors mediate prostaglandin synthesis in human astrocytes. Hypertension (Dallas). 17:1115-1120.

57. Chen, L., O. Prakash, and R.N. Re. 1993. The interaction of insulin and angiotensin II on the regulation of human neuroblastoma cell growth. Mol. Chem. Neuropathol. 18:189-196.

58. Brilla, C.G., G. Zhou, L. Matsubara, and K.L. Weber. 1994. Collagen metabolism in cultured adult rat cardiac fibroblast: response to angiotensin II and aldosterone. J. Mol. Cell Cardiol. 26:809-820. 